\title{
GROWTH OPPORTUNITIES UTILIZATION: DEBT OVERHANG OR ASYMMETRIC INFORMATION?
}

\author{
S. MARTONO*, Arief YULIANTO**, Angga Pandu WIJAYA*** \\ Universitas Negeri Semarang, Faculty of Economics, Department of Management, INDONESIA \\ *e-mail: martono@mail.unnes.ac.id \\ **e-mail: ariefyulianto@mail.unnes.ac.id \\ ***e-mail: apwijaya@mail.unnes.ac.id
}

\begin{abstract}
Inter-industry has various capital structures to take advantage of growth opportunities due to agency differences and information asymmetric problems. This research aims to analyze: (1) the differences in leverage between industries and (2) the impact of shareholders-debtholders conflict and information asymmetric on growth opportunities. The firm-level data used is extracted from Indonesia Stock Exchange's annual reports from 2008 to 2019. Authors used the analysis of variance (ANOVA). The findings show differences in leverage between industries. However, they are relatively stable and not excessive for assets to prevent conflicts between managers and shareholders with debtholders. Equity is also not used to utilize growth to reduce the discretionary power (dilution) of shareholders. As a result, the use of opportunities and growth is limited. This study identifies agency problems and asymmetric information that determines independent companies' decisions in exploiting growth opportunities.
\end{abstract}

Keywords: independent company, agency problem, information asymmetric.

JEL Classification: G24, G30, G32.

\section{Introduction}

Previous literature has discussed the relationship between modern companies' roles and functions, assuming widely dispersed ownership. However, different results show large companies outside the US, which tend to be owned by controlling shareholders through excess cash flow rights (La Porta, et al., 1999). In Indonesia, Japan, and Singapore, more than two-thirds of the companies are owned by single shareholders (Claessens, et al., 2000). Separation of ownership and control functions is rarely implemented, and around $60 \%$ of the top management are family members who also act as shareholders.

This study elaborates and develops the research conducted by Claessens, et al. (2000) on the findings in Indonesia through two perspectives: agency theory and asymmetric information theory. The agency theory refers to when managers act independently from the company shareholders' interests. For example, they might reject a potential net present value (NPV) project as long as they benefit debtholders (Myers, 1977). As an implication, the company could lose growth opportunities (La Rocca, et al., 2007). The second theory - asymmetric information - results in debtholders preventing opportunistic behavior by limiting debt and increasing the interest rates (Cariola, et al., 2011).

This study finds extensive research related to underinvestment problems resulting in lost growth opportunities (Claessens, et al., 2000). Between 2009 and 2019, debt use tended to be stable, indicating that companies had prevented debt from an overhang. As a result, it does not exploit growth opportunities. Senior shareholders will avoid issuing shares that result in dilution or loss of discretionary power for Indonesian companies characterized by a controlling shareholder's existence. Older companies have a lower level of asymmetric information and vice versa. This situation causes companies' conditions to be independent of debt because it could take advantage of equity, thereby taking advantage of growth opportunities.

The evidence also suggests a slight difference in leverage, age, and size of the firm due to the type of industry, that is, $16.9 \%, 2.3 \%$, and $3.9 \%$, respectively. Even though growth opportunities are inter-industrial, companies still prefer to limit debt. Only older companies with low information asymmetry will reduce the utilization of growth opportunities. Interestingly, previous research found that to avoid the chance 
to lower growth opportunities, shareholders would limit conflict with debtholders, while simultaneously avoiding investing in new shares that could cause dilution. Warijo (2015) explained that Indonesia has a solid bank-based system compared to the capital market, forcing banks to offer many debts to the companies. This bank-based system's presence causes weak good governance, which in 1998 caused an economic crisis (Sadia, et al., 2013). Excessive debt and concentrated majority ownership on shareholders cause many multiplier effects on bankruptcies and lost opportunities to take advantage of growth across industries. This situation encourages companies to auction off assets to fulfill their obligations to debtholders without providing shareholders benefits. Therefore, this research aims to analyze and test the difference in inter-industry debt ratios after 20 years of crisis. Furthermore, this study identifies agency problems and asymmetric information that determines independent companies' decisions in exploiting growth opportunities.

\section{Literature review}

\subsection{Agency problem of capital structure}

The conflict between managers, shareholders, and debtholders is caused by differences in the interests of in-place financing assets to take advantage of growth opportunities based on the ability to generate profitable investments. With information asymmetry and incomplete nexus contracts, this conflict could lead managers to act based on two interests: their interest as a debtholder or as a shareholder (Cariola, et al., 2011; La Rocca, et al., 2007). Suppose they act based on their interests as a debtholder. In that case, the investment decision could be detrimental to shareholders' interests because debtholders are prone to making riskless investments despite low returns. On the other hand, investments made in shareholders' interests through suboptimal investments, oriented to maximizing equity value and not corporate value, could also be detrimental to debtholders. In turn, this could elicit conflict between senior new shareholders.

The underinvestment problem is related to debt overhang (Myers, 1977). Companies with high leverage and managers who act in the interests of shareholders will reject positive NPV projects. For debtors, debt becomes riskier (risky debt) because of the increased risk of financial difficulties and company bankruptcy. Ultimately, the debt does not pay off. On the other hand, the manager will not choose the project because it only benefits debtholders without additional benefits to shareholders. This situation results in a conflict of interest for shareholders and debtholders due to a debt overhang. Debt is a "tax" because the company must firstly pay the principal and loan interest to debtholders, while shareholders only receive its residual (Stein, 2001). Even though the project has a positive NPV, as long as it does not provide significant benefits to shareholders, the manager would refuse (underinvestment), thus becoming a risky debt for debtholders. When the company is independent and has an overhang, the impact on reducing investment incentives is that opportunities to exploit growth are limited (Mondosha and Majoni, 2018). When assets in place are financed by debt, it influences the decision to take advantage of and create growth opportunities. Because in this way, it puts pressure on the quality of investment decisions, which is based not only on cash flow, but also on the project's ability to provide more residuals to shareholders (Cariola, et al., 2011). This situation results in the indebted company losing the opportunity to grow because it refuses all projects that only benefit debtholders.

Specifically, investment choices are related to growth opportunities and financial conditions (Brito and John, 2005; Cariola, et al., 2011). First, when growth opportunities are high and financial conditions are good, the optimal investment will occur. Second, when growth opportunities are low and financial conditions are poor (high leverage), debt overhang or underinvestment occurs (Myers, 1977). Third, when growth opportunities are high and financial conditions are bad (leverage is high), risk avoidance occurs (Brito and John, 2005). Conversely, when growth opportunities are low and financial conditions are poor (high leverage), risk shifting occurs (Jensen and Meckling, 1976). So, this high-leverage situation generates various possibilities for the discretion of managers who side with the interests of shareholders, who explore the use of growth opportunities.

Manager agency problems' discretion in allocating investment resources has an impact on asymmetric information (Degryse and Jong, 2001). The presence 
of untapped growth opportunities creates agency costs of risky debt, such as risk avoidance, risk shifting, and underinvestment. This agency problem produces information asymmetry between shareholders (managers) and debtholders. When debtholders cannot determine the quality of information regarding shareholders' investment decisions (asymmetric information), it will increase the agency cost of debt. It will limit lending and increase the interest rates. The presence of new shares results in a dilution, reducing the power of the past stakeholders. As an implication, conflicts between new and old shareholders arise (Cariola, et al., 2011).

The information asymmetry problem is generated because debtholders prevent managers' opportunistic behavior from acting on shareholders' interests. Such cases are found in specific firm forms, such as age and size (Degryse and Jong, 2001). Information from older companies is more exposed than from younger firms (Tayem, 2018), lowering the level of asymmetric information. In addition to firm age, asymmetric information is generated from firm size. Large companies tend to have fewer information asymmetry problems, whereas small companies with high growth have higher information asymmetry (Frank and Goyal, 2003; Tayem, 2018). Having better governance and financial analysts and gaining public attention cause larger companies to have lower information asymmetry levels (Hwang, et al., 2019). In other words, older and larger companies have less asymmetric information, allowing them to obtain equity funding when a debt overhang occurs. At the same time, companies can continue to take advantage of growth opportunities other than debt.

\subsection{Leverage inter-industry}

This paper divides the explanation of industries' leverage variation based on two causes: agency problems and asymmetric information. First, the global crisis of 1997-1998 and the bailout in Europe in 2008 significantly impacted Indonesia. They provided lessons for private sectors about the need to reduce the debt ratio in anticipation of increased risk (Nursechafia and Muthohharoh, 2014). The crisis was caused by the weak implementation of corporate governance with family control, business group affiliation, cash flow control, and political connections (Harijono and
Tanewski, 2012). All companies across industries have excessive debt ratios, so the impact of the crisis is across industries. As a result, shareholders do not receive any residual because the bankruptcy effect leaves debtors to fulfill obligations.

In this research, the influence of the 1998 Indonesian crisis is not considered because it is no longer relevant to the present situation. The current situation is more accurately described as a pre-crisis form. The differences in risk cause differences in the inter-industry leverage. However, the intra-industry leverage level is relatively similar due to its business and risk homogeneity that tends to stabilize over time (Das and Roy, 2007). Das and Roy (2007) explained that leverage between industries tends to vary, depending on industry characteristics. In industries with low growth and high leverage, managers' decisions limit investment. Companies in the same industry have relatively no different capital structures (e.g., computer software, oilfield services, pharmaceutical). However, in other industries, the capital structure is entirely different (e.g., aluminum, food wholesale, drugstores) (Almazan and Molina, 2005). More specifically, companies with more leverage than the target will reduce investment capital expenditures, which does not happen to under-leveraged companies. Thus, inter-industry leverage varies depending on the agency problem that results from inherent leverage.

Second, the difference in leverage between industries is the asymmetric information produced by variations in the inter-industry companies' size and age. Some literature finds that firm size is inversely related to information asymmetry (Degryse and Jong, 2001). They specifically explained that greater information asymmetry is found in smaller firms because of the high cost of obtaining information. Additionally, fixed assets are easier to value than non-fixed assets. Hence, companies with more considerable fixed assets can use them as collateral to limit financial constraints. The three company track records are visible from age. Older companies have lower information asymmetry by providing information that is easily accessible to the public. Also, inter-industry has different characteristics from the debtors' perspective, such as the need for assets and the business cycle (Leclerc, 2016). 
Furthermore, large-sized companies have more funding options compared to small-sized companies. Age, measured since going public, impacts funding sources' heterogeneity (Almazan and Molina, 2005). Large companies have better governance and better disclosure, so that information asymmetry is lower this difference in information asymmetry results in the differences in independent companies' opportunity to grow.

This study employs industry measurements - variations in mean leverage between industries - (Graham and Leary, 2011). This choice is made because of the assumption that the mean leverage between industries is not different (Das and Roy, 2007). Also, time series data is used to determine variations in leverage as a proxy agency problem and information asymmetry. The increase in leverage time series shows the potential for a debt overhang to occur, producing conflict between shareholders and debtholders. Additionally, ex-ante information asymmetry results in a decrease in leverage.

\subsection{Effect of leverage, firm age, and firm size on growth}

Managers' discretion in increasing firm value depends on choosing a profitable investment based on future growth opportunities (Myers, 1977). With discretionary power, they can make decisions based on shareholders' interests, potentially causing conflicts with debtholders, such as underinvestment (Cariola, et al., 2011; Jensen and Meckling, 1976).

When managers make decisions to increase firm value, they select all projects with a positive NPV, but high debt prompts them to act entirely differently. The presence of high debt as risky debt results in their decision to reject a project with a positive NPV because, if the investment is successful, it will only benefit the debtholder, namely debt market value exceeds the nominal value without generating benefits for shareholders (Cariola, et al., 2011; Myers, 1977). If the investment fails, they must still pay debts and principal loans to debtholders, such as the tax on profit from the investment made (Stein, 2001).

Underinvestment due to agency problems and ex-ante information asymmetry causes debtholders to make adverse choices, preventing managers' and shareholders' opportunistic behavior by limiting credit or increasing loan interest rates. The uncertainty regarding the quality of investment information has resulted in risky debt and increased debt costs for debtholders. This condition encourages various actions from the managers. First, a risky debt would drive managers to reject projects with positive NPV, which could cause them to lose growth opportunities. Thus, higher leverage increases the chance for projects with positive NPV to be rejected. The underinvestment hypothesis explains that risky debt decreases debt from the total resources meant for new investments.

Hypothesis 1: The number of resources for new investments is lower than planned, limiting companies from taking growth opportunities and creating economic value.

The second hypothesis related to risk is risk shifting; leverage positively affects growth opportunities (Jensen and Meckling, 1976). They explained that shareholders would invest when the level of risk is above average. The fact is that companies do risk shifting when there is an increase in leverage, so there is an increase in the risk of bankruptcy and financial difficulties. On the contrary, risk avoidance, namely the increase in leverage, does not significantly impact investment in growth opportunities (Brito and John, 2005). Managers tend to make investment decisions that do not exceed the average risk for peers, in order to protect their control over the company. This situation can ultimately lower future growth opportunities.

The demand for the premium cost of debt can be reduced by the presence of a debt covenant, which can control the conflict between shareholders and debtors over the implementation of growth options to use low debt (Billett, et al., 2007). Apart from the Anglo and American models, debt covenants are different in large developing economies such as China, India, Brazil, and second-tier developing economies such as Indonesia and South Africa and new market economies such as Russia (Taylor, 2013). In Indonesia, debt covenants' implementation has not reduced debtholders' and share methods' conflicts, so there is still high interest for indebted companies (Rossieta, 2009). So, in the absence of a debt covenant, information asymmetry results in debtholder precautions against 
managers and shareholders through increased interest rates.

Consequently, companies choose to invest in lower debt options, even though it offers high growth opportunities (Ari, 2017; Billett, et al., 2007). Growth opportunities are not utilized in debt overhang companies with a high level of asymmetry.

Hypothesis 2: Large and older companies have a lower level of asymmetry, which allows them to have equity funding when a debt overhang occurs.

\section{Data Description}

Industry classification is based on the Indonesia Stock Exchange (IDX) and the financial industry division, such as banking, financing institutions, insurance, because we have different capital structures. The 1st and 100th percentiles of the sample data (i.e., leverage, growth, firm size, and age) have been removed to obtain balanced data because it contains extreme values and the population distribution is unknown (Müller, 2011). All results reported in this paper relate to trimmed data.

The firm-level data used is extracted from the IDX's annual reports from 2008 to 2019. We use the leverage as proxy debt-to-asset ratio for the independent variable as a proxy for agency problems (Popov and Barbiero, 2018). An increase in the debt-to-asset ratio reduces investment by a quarter of the standard deviation. The overhang mechanism explains that an increase in debt ratio to assets will reduce shareholders' rights in assets because it will be given to debtholders for the first time (Myers, 1977).

The independent variable as a proxy for our information asymmetry uses firm size and firm age. Smaller companies tend to have more prominent asymmetry (internal information) problems (Hwang, et al., 2019). Furthermore, large-sized companies have more funding options than small-sized companies. Age, measured since going public, impacts funding sources' heterogeneity (Almazan and Molina, 2005). The current authors use the proxy Ln (total assets) for size and Ln (Age) for age. Therefore, the research aim is to examine and analyze a number of resources for new investment and asymmetry information at the company level. The research supposes that the number of resources for new investments is lower than planned, limiting companies from taking growth opportunities and creating economic value. The research presumes that large and older companies have a lower level of asymmetry, which allows them to have equity funding when a debt overhang occurs.

Regarding the research stages, the first author developed research gap and purpose. Second, data from IDX was collected. Third, the author examined the obtained data. According to Moreira (2017), differences in the industry's characteristics would result in differences in leverage. For this reason, the authors used the analysis of variance (ANOVA). Furthermore, to determine the effect of leverage, firm age, and firm size, multiple regression analysis of panel data was conducted using SPSS.

Table 1. Result of correlation analysis (Source: IDX Statistics, 2009-2019)

\begin{tabular}{|l|c|c|c|c|}
\hline & Debt to Assets Ratio & Age & Size & Growth sales \\
\hline Debt to Assets Ratio & 1 & 0.033379 & 0.111995 & 0.007558 \\
\hline Age & 0.033379 & 1 & 0.045458 & -0.06881 \\
\hline Size & 0.111995 & 0.045458 & 1 & 0.009209 \\
\hline Growth sales & 0.007558 & -0.06881 & 0.009209 & 1 \\
\hline
\end{tabular}

Data were collected from 2327 units of observation (whole industry [WI]): 4.86\% from agriculture (A) industry, $13.45 \%$ from the basic industry and chemicals (BIC) industry, $8.89 \%$ from the consumer goods in- dustry (CGI), $12.46 \%$ from the infrastructure, utilities, and transportation (IUT) industry, 9.92\% from the mining $(\mathrm{M})$ industry, $6.96 \%$ from miscellaneous industry (MI), 16.41\% from property, real estate, and 
building construction (PRB) industry, and 27.03\% from trade, services, and investment (TSI).

These data obtained from IDX as openness of information as represented in Table 1. Our empirical approach explains how the independent variables are related to growth opportunities as the dependent variable. The correlation results showed that the relationship between the independent variables was low, so regression analysis was carried out.

\section{$4 \quad$ Findings and Results}

\subsection{Difference in inter-industry leverage}

The skewness data showed that industry A, TSI, and WI had a leverage level below the median. Aside from all three industries mentioned above, all the remaining industries had a leverage level above the median. Thus, there was a difference in the leverage level of industry A, TSI, and WI with the remaining sectors. This result in Table 2 indicates that differences in risk and firm characteristics could result in differences in leverage.

Table 2. Descriptive statistics on inter-industry leverage (Source: IDX Statistics, 2009-2019)

\begin{tabular}{|l|c|c|c|c|c|c|c|c|}
\hline \multicolumn{1}{|c|}{ Industry } & $\mathrm{n}$ & Mean & $\begin{array}{c}\text { Standard } \\
\text { deviation }\end{array}$ & $\begin{array}{c}\text { 25th per- } \\
\text { centiles }\end{array}$ & Median & $\begin{array}{c}75 \text { th per- } \\
\text { centiles }\end{array}$ & Kurtosis & Skewness \\
\hline Agriculture & 113 & 0.452 & 0.226 & 0.257 & 0.468 & 0.607 & 5.464 & 1.147 \\
\hline $\begin{array}{l}\text { Basic industry and } \\
\text { chemicals }\end{array}$ & 313 & 0.479 & 0.195 & 0.334 & 0.471 & 0.616 & -0.757 & 0.111 \\
\hline $\begin{array}{l}\text { Consumer goods } \\
\text { industry }\end{array}$ & 207 & 0.404 & 0.170 & 0.262 & 0.388 & 0.541 & -0.890 & 0.231 \\
\hline $\begin{array}{l}\text { Infrastructure, } \\
\text { utilities, and trans- } \\
\text { portation }\end{array}$ & 290 & 0.520 & 0.176 & 0.399 & 0.533 & 0.650 & -0.447 & -0.290 \\
\hline Mining & 231 & 0.478 & 0.195 & 0.318 & 0.463 & 0.616 & -0.669 & 0.224 \\
\hline $\begin{array}{l}\text { Miscellaneous in- } \\
\text { dustry }\end{array}$ & 162 & 0.508 & 0.189 & 0.367 & 0.491 & 0.660 & -0.959 & 0.051 \\
\hline $\begin{array}{l}\text { Property, real es- } \\
\text { tate, and building } \\
\text { construction }\end{array}$ & 382 & 0.462 & 0.175 & 0.336 & 0.474 & 0.581 & -0.610 & 0.118 \\
\hline $\begin{array}{l}\text { Trade, services, } \\
\text { and investment }\end{array}$ & 629 & 0.480 & 0.219 & 0.321 & 0.468 & 0.633 & 13.305 & 1.530 \\
\hline Whole industry & 2327 & 0.476 & 0.198 & 0.327 & 0.474 & 0.618 & 5.549 & 0.693 \\
\hline
\end{tabular}

Table 3. ANOVA test on leverage in inter-industry (Source: IDX Statistics, 2009-2019)

\begin{tabular}{|l|c|c|c|c|c|c|c|}
\hline \multicolumn{1}{|c|}{ Sources } & SS & \multicolumn{1}{c|}{ df } & MS & F & P-value & F crit & RMSSE \\
\hline Between groups & 1.952 & 8 & 0.244 & 6.305 & 0.000 & 1.940 & 0.169 \\
\hline Within groups & 179.710 & 4645 & 0.039 & - & - & - & - \\
\hline Total & 181.661 & 4653 & 0.039 & - & - & - & - \\
\hline
\end{tabular}

The research found $16.9 \%$ variations in leverage due to differences between inter industries (RMSSE value in Table 3). Leverage firms had a greater variation than unleveraged firms due to the free cash flow hypothesis (Jensen and Meckling, 1976). The free cash flow argument explains that a different growth rate characterizes each industry, so that leverage also varies (Das and Roy, 2007). We present the Fig. 1 in time series data for 2009-2019. The mean leverage in inter-industry is relatively stable, indicating that managers acting in shareholders' interests prevent conflicts with debtholders and encourage avoidance of debt overhang. 

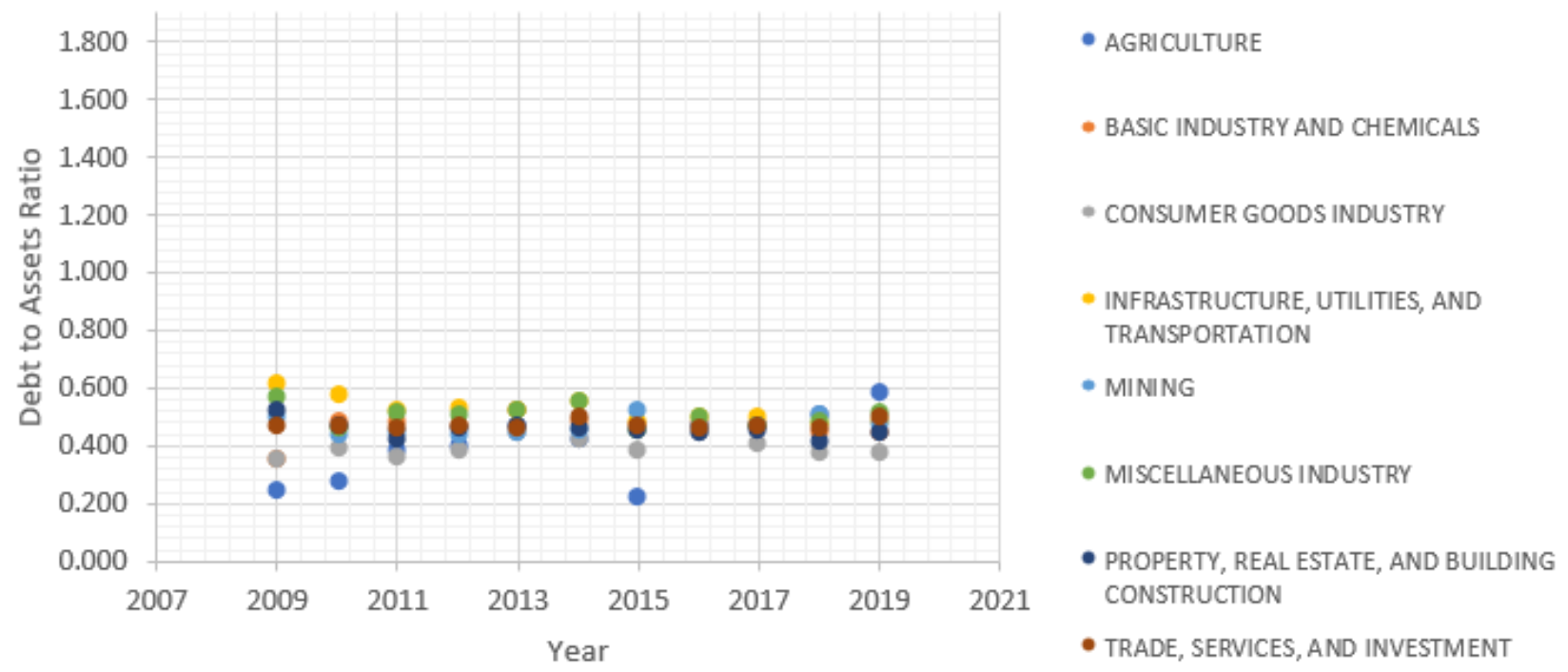

Figure 1. Time series on inter-industry debt to assets ratio (Source: IDX Statistics, 2009-2019)

Table 4. Time series data on firm age (Source: IDX Statistics, 2009-2019)

\begin{tabular}{|l|l|l|l|l|l|l|l|l|l|l|l|}
\hline & 2009 & 2010 & 2011 & 2012 & 2013 & 2014 & 2015 & 2016 & 2017 & 2018 & 2019 \\
\hline Agriculture & 0.252 & 0.281 & 0.387 & 0.404 & 0.476 & 0.432 & 0.227 & 0.481 & 0.475 & 0.513 & 0.591 \\
\hline $\begin{array}{l}\text { Basic industry and } \\
\text { chemicals }\end{array}$ & 0.361 & 0.495 & 0.497 & 0.473 & 0.527 & 0.493 & 0.485 & 0.487 & 0.490 & 0.449 & 0.447 \\
\hline $\begin{array}{l}\text { Consumer goods in- } \\
\text { dustry }\end{array}$ & 0.363 & 0.393 & 0.375 & 0.389 & 0.448 & 0.432 & 0.387 & 0.448 & 0.417 & 0.383 & 0.378 \\
\hline $\begin{array}{l}\text { Infrastructure, utili- } \\
\text { ties, and transporta- } \\
\text { tion }\end{array}$ & 0.616 & 0.583 & 0.534 & 0.544 & 0.529 & 0.559 & 0.493 & 0.505 & 0.503 & 0.483 & 0.492 \\
\hline $\begin{array}{l}\text { Mining } \\
\text { Miscellaneous in- } \\
\text { dustry }\end{array}$ & 0.574 & 0.468 & 0.518 & 0.511 & 0.530 & 0.554 & 0.459 & 0.508 & 0.474 & 0.498 & 0.524 \\
\hline $\begin{array}{l}\text { Property, real es- } \\
\text { tate, and building } \\
\text { construction }\end{array}$ & 0.531 & 0.474 & 0.431 & 0.470 & 0.479 & 0.467 & 0.460 & 0.452 & 0.455 & 0.428 & 0.446 \\
\hline $\begin{array}{l}\text { Trade, services, and } \\
\text { investment }\end{array}$ & 0.477 & 0.475 & 0.466 & 0.477 & 0.472 & 0.503 & 0.473 & 0.469 & 0.478 & 0.467 & 0.505 \\
\hline Minimal & 0.460 & 0.452 & 0.458 & 0.464 & 0.489 & 0.488 & 0.440 & 0.478 & 0.472 & 0.467 & 0.484 \\
\hline Maximal & 0.252 & 0.281 & 0.375 & 0.389 & 0.448 & 0.432 & 0.227 & 0.448 & 0.417 & 0.383 & 0.378 \\
\hline
\end{tabular}

In 2009, the mean leverage was the most varied, while low variation was evident in 2013, indicating the need for leverage in response to growth differences. Companies in inter-industry tend to take time series to try to prevent agency conflicts (Almazan and Molina, 2005).

Furthermore, the difference in firm age and firm size intra-industry determined by ANOVA is reported in Table 4. 


\subsection{Difference between age and size in inter-industry}

Companies in inter-industry had a mean age below the median age, and with a negative kurtosis, it was relatively heterogeneous as depicted in Table 5. The mean age variation was more significant in the CGI and MI industries than in other industries.
The research found $2.3 \%$ variations in age due to differences between inter industries (RMSSE value in Table 6), and was below the median (positive skewness), and that inter-industry had mean age heterogeneity (negative kurtosis).

Table 5. Data description on firm age intra-industry (Source: IDX Statistics, 2009-2019)

\begin{tabular}{|l|c|c|c|c|c|c|c|c|}
\hline \multicolumn{1}{|c|}{ Industry } & $\mathrm{n}$ & Mean & $\begin{array}{c}\text { Standard } \\
\text { deviation }\end{array}$ & $\begin{array}{c}25 \text { th per- } \\
\text { centiles }\end{array}$ & Median & $\begin{array}{c}75 \text { th per- } \\
\text { centiles }\end{array}$ & Kurtosis & $\begin{array}{c}\text { Skew- } \\
\text { ness }\end{array}$ \\
\hline Agriculture & 113 & 2.470 & 0.596 & 2.197 & 2.485 & 3.091 & 0.866 & -0.682 \\
\hline $\begin{array}{l}\text { Basic industry } \\
\text { and chemicals }\end{array}$ & 313 & 2.761 & 0.699 & 2.303 & 3.135 & 3.219 & 1.414 & -1.468 \\
\hline Consumer goods industry & 207 & 2.747 & 0.720 & 2.197 & 3.178 & 3.258 & 0.708 & -1.328 \\
\hline $\begin{array}{l}\text { Infrastructure, utilities, } \\
\text { and transportation }\end{array}$ & 290 & 2.293 & 0.633 & 1.946 & 2.197 & 2.773 & 0.253 & -0.641 \\
\hline Mining & 231 & 2.581 & 0.472 & 2.303 & 2.485 & 2.944 & 2.355 & -0.960 \\
\hline Miscellaneous industry & 162 & 2.803 & 0.719 & 2.485 & 3.135 & 3.296 & 2.173 & -1.612 \\
\hline $\begin{array}{l}\text { Property, real estate, and } \\
\text { building construction }\end{array}$ & 382 & 2.620 & 0.622 & 2.303 & 2.602 & 3.178 & 1.080 & -1.041 \\
\hline $\begin{array}{l}\text { Trade, services, } \\
\text { and investment }\end{array}$ & 629 & 2.583 & 0.627 & 2.079 & 2.773 & 3.091 & 0.727 & -0.995 \\
\hline Whole industry & 2327 & 2.601 & 0.653 & 2.197 & 2.708 & 3.178 & 0.697 & -1.006 \\
\hline
\end{tabular}

Table 6. ANOVA test on firm age intra-industry (Source: IDX Statistics, 2009-2019)

\begin{tabular}{|l|c|c|c|c|c|c|c|c|}
\hline \multicolumn{1}{|c|}{ Sources } & SS & Df & MS & F & $P$-value & F crit & RMSSE & $\begin{array}{c}\text { Omega } \\
\text { Sq. }\end{array}$ \\
\hline Between groups & 48.950 & 8 & 6.119 & 14.682 & 0.000 & 1.940 & 0.245 & 0.023 \\
\hline Within groups & 1935.800 & 4645 & 0.417 & - & - & - & - & - \\
\hline Total & 1984.750 & 4653 & 0.427 & - & - & - & - & - \\
\hline
\end{tabular}

Table 7 show negative skewness was found when most companies in industries A, CGI, M, and PRB had total assets above the median, while others had them below the median. Industry A and MI had a positive kurtosis, so the total assets' variation was lower than those owned by other sectors.

The findings found 3.9\% variations in size due to differences between inter industries (RMSSE value in Table 8), The variation in total assets was greater in the CGI because it grew larger than others in the observation period.

The findings show that (1) there is a low correlation between the independent variables and (2) there are differences in leverage, age, and sizes between industries. The findings of the independence of the independent variables and inter-industry differences are predicted not to produce a growth opportunity bias, allowing regression testing to be carried out. 
Table 7. Descriptive statistics on firm size (Source: IDX Statistics, 2009-2019)

\begin{tabular}{|l|c|c|c|c|c|c|c|c|}
\hline \multicolumn{1}{|c|}{ Industry } & $\mathrm{n}$ & Mean & $\begin{array}{c}\text { Standard } \\
\text { devia- } \\
\text { tion }\end{array}$ & $\begin{array}{c}25 \text { th per- } \\
\text { centiles }\end{array}$ & $\begin{array}{c}\text { Me- } \\
\text { dian }\end{array}$ & $\begin{array}{c}75 \text { th per- } \\
\text { centiles }\end{array}$ & $\begin{array}{c}\text { Skew- } \\
\text { ness }\end{array}$ & $\begin{array}{c}\text { Kurto- } \\
\text { sis }\end{array}$ \\
\hline Agriculture & 113 & 29.262 & 1.162 & 28.609 & 29.335 & 30.084 & -0.625 & 0.364 \\
\hline $\begin{array}{l}\text { Basic industry and } \\
\text { chemicals }\end{array}$ & 313 & 28.365 & 1.329 & 27.460 & 28.369 & 29.168 & 0.339 & -0.140 \\
\hline $\begin{array}{l}\text { Consumer goods } \\
\text { industry }\end{array}$ & 207 & 28.083 & 1.284 & 27.206 & 27.926 & 28.845 & 0.444 & -0.014 \\
\hline $\begin{array}{l}\text { Infrastructure, utilities, } \\
\text { and transportation }\end{array}$ & 290 & 28.856 & 1.531 & 27.886 & 28.752 & 29.809 & -0.004 & -0.692 \\
\hline Mining & 231 & 29.118 & 1.468 & 28.242 & 29.205 & 30.259 & -0.517 & -0.359 \\
\hline $\begin{array}{l}\text { Miscellaneous } \\
\text { industry }\end{array}$ & 162 & 28.090 & 1.229 & 27.186 & 27.730 & 28.631 & 0.960 & 0.025 \\
\hline $\begin{array}{l}\text { Property, real estate, } \\
\text { and building construc- } \\
\text { tion }\end{array}$ & 382 & 28.899 & 1.338 & 28.038 & 28.942 & 29.893 & -0.188 & -0.311 \\
\hline $\begin{array}{l}\text { Trade, services, } \\
\text { and investment }\end{array}$ & 629 & 28.161 & 1.433 & 26.890 & 28.197 & 29.243 & 0.046 & -0.527 \\
\hline Whole industry & 2327 & 28.533 & 1.439 & 27.434 & 28.515 & 29.563 & 0.045 & -0.572 \\
\hline
\end{tabular}

Table 8. ANOVA test on firm size intra-industry (Source: IDX Statistics, 2009-2019)

\begin{tabular}{|c|c|c|c|c|c|c|c|c|}
\hline Sources & SS & Df & MS & $\mathrm{F}$ & P-value & F crit & RMSSE & $\begin{array}{c}\text { Omega } \\
\text { Sq. }\end{array}$ \\
\hline Between groups & 389.996 & 8 & 48.750 & 24.481 & 0.000 & 1.940 & 0.321 & 0.039 \\
\hline Within groups & 9249.644 & 4645 & 1.991 & - & - & - & - & - \\
\hline Total & 9639.640 & 4653 & 2.072 & - & - & - & - & - \\
\hline
\end{tabular}

Several cross-country studies have shown firm age and firm size are the factors that make information asymmetry. A research by Das and Roy (2007) examined cross-sectional data in India and the result showed that there were differences in the inter-industry debt ratio between the pre- (1979-1980) and postliberalization periods (1998-1999). The difference is due to the size of the company and the varied interindustry needs, where technology-based industries have a larger debt ratio than the other. Although it appears that after liberalization, larger firms were given better access to banking and capital markets than preliberalization, this policy is inconsistent. In more detail, Aminadav and Papaioannou (2016) explain that companies in India have a concentrated ownership structure within $30 \%$.

During the non-tradable shares (NTS) reform period in China, Qu, et al. (2018) found that varying information asymmetry resulted in differences in debt ratios across industries. The presence of information asymmetry causes good-quality companies to issue debt the same way as bad-quality companies. As a result, debt issued by good-quality companies is undervalued and bad-quality companies are overvalued. $\mathrm{Qu}$, et al. (2018) explained, the NTS period 20072007 within $72 \%$ is State-Owned Enterprises (SOE) or other government agencies, where the government has approximately $20 \%$ share ownership. As a result, the government's backing to SOE increases debt because the government is oriented toward political, social, and tax revenue motivation factors for SOE.

A study by Maria, et al. (2019) conducted in 15 European Union countries by adding industry and country variables in dummy regression reported differences in capital structure across the industry. The level of information asymmetry in each life cycle stage, which varies, results in different financing decisions. More young firms have less information asymmetry than old firms; as a result, older firms can access more nonbank funding sources than younger firms. 
The concentrated ownership structure produces agency problems between managers with investor (shareholders with debtholders). Akerlof (1970) describes a used car market that sells plums and lemons, resulting in adverse selection problems and moral hazards. When managers act to serve the interests of shareholders faced with investment choices, they will issue equity when overvalued and will pass up investment projects when undervalued. Thus, the issuance of equity conveys negative information to the market. Therefore, when there is information asymmetry, the company uses internal funds first, then risky debt and, in turn, equity, as explained by Pecking Order Theory (POT).

The previous paper proved that firm age and firm size produce asymmetric information, so that companies follow the POT hierarchy, which prefers debt over equity. However, when companies use more leverage, it will have an impact on exploiting future growth opportunities. There are two possible outcomes: first, debt overhang, where the company will pass up future growth opportunities with a positive NPV because it only increases the welfare of debtholders and second, overinvestment, where companies take advantage of future growth opportunities with negative NPV because with the limited liability of shareholders, this situation results in losses for debtholders. Next, we report the regression results to find out information asymmetry on the utilization of growth opportunities.

\subsection{How is growth sales with the presence of a debt ratio, firm age, and firm size}

Firm value is generated from financed assets in exploiting growth opportunities through profitable investment (Myers, 1977). The managers of independent companies have discretion in making investment decisions based on shareholders' interests, causing them to reject investments with positive NPV (underinvestment). Debt overhang causes companies to lose growth, turning it into a risk for debtholders. The situation above encourages agency conflicts between shareholders and debtholders, impacting the companies' inability to pay debts. The increased risk of companies being unable to pay the debt causes debtholders to raise interest rates and limit lending, forcing shareholders to seek cheaper external funding sources (i.e., capital market). In-place asset financing or inter-industry DAR ranges from $22.7 \%$ to $61.6 \%$. Thus, the company keeps the debt from becoming overhang from time to time. Managers often decide to underinvest or conduct risk shifting when a debt overhang occurs, causing a decrease in growing sales. However, leverage does not affect sales growth (model 2). As a result, there is no underinvestment or risk shifting.

In East Asia, including Indonesia, ownership structure does not separate ownership and control, allowing managers to always act in shareholders' interests (Claessens, et al., 2000). The ownership structure of companies in Indonesia tends to be concentrated, with $65.14 \%$ controlled by the majority shareholders and $66.45 \%$ owned by individuals or groups or families (Rusmin, et al., 2011). They added that, in some cases, family members are also placed as independent commissioners to maintain family control over the company. To maintain control and prevent this conflict, family companies will identify their members as debtholders (Villalonga, et al., 2015)

Shareholders have an interest in maintaining the family company or controlling shareholders. Thus, in older companies, the ownership structure tends to be concentrated. Shareholders do not want to lose ownership to long-running companies, so they maintain the debt level not to cause debt overhang. This condition triggers shareholders to avoid risky debt, so that the interest of the debtholders is maintained. As such, the relationship between debtholders and shareholders can be in line with one another. Companies in Indonesia are primarily family owned and are more oriented toward ensuring long-term goals, safeguarding family reputation, and maintaining togetherness by not diversifying the ownership (Anderson, et al., 2005).

The existence of agency problems between shareholders and bondholders results in asymmetric information. Bondholders do not know the quality of investment information because of the opportunistic managers and shareholders. The results, bondholders limiting lending and increasing the interest rate. No agency problem is evident, but information asymmetry is an issue that negatively affects growth sales.

Model 2 shows that older firms have fewer information asymmetry problems. 
The age measured since going public impacts the heterogeneity of funding sources (Almazan and Molina, 2005). Table 9 represent companies growth sales, As an implication, companies have sources of funding other than debt. Agency problems do not coincide with asymmetric information, in contrast to the initial hypothesis that explains the relationship (Cariola, et al., 2011; La Rocca, et al., 2007).

Table 9. Regression analysis (Source: IDX Statistics, 2009-2019)

\begin{tabular}{|l|c|c|}
\hline \multicolumn{1}{|c|}{ Dependent variable: growth sales } & 1 & 2 \\
\hline Debt asset ratio & 0.009 & 0.010 \\
\hline P-value & 0.716 & 0.680 \\
\hline Age & - & $-0.024^{*}$ \\
\hline P-value & - & 0.001 \\
\hline Size & - & 0.002 \\
\hline P-value & - & 0.584 \\
\hline $\mathrm{R}^{2}$ & 0.000 & 0.005 \\
\hline Adj. $\mathrm{R}^{2}$ & 0.000 & 0.004 \\
\hline No. observation & 2327 & 2327 \\
\hline * sig at 5\% & & \\
\hline
\end{tabular}

Older companies have less asymmetric information because they provide better information compared to smaller companies. Thus, the public becomes more aware of older companies' information than that of younger companies (Tayem, 2018). As a result, when there is no debt overhang due to risky debt, older companies tend to lower growth opportunities. An older company without agency conflict and asymmetric information has higher retention of control. Shareholders can obtain external funds more quickly because there is no information asymmetry problem, but they still use debt and experience debt overhangs. Older companies concentrate more on ownership (Claessens, et al., 2000) and still prioritize debt as a funding source. They are afraid of losing their company during a debt overhang, resulting in asset takeover by debtholders. Martinez, et al. (2019) provide similar evidence, when the age of a company that produces asymmetric information. The older firms, and with smaller asymmetry information results in a decrease in the utilization of growth opportunities.

The impact is the use of growth opportunities through debt restriction, although it can increase debt because there is no information asymmetry. Without agency conflict, the information asymmetry caused by the firm size only increases by $1 \%$, so it has a significant probability of increasing the growth opportunity by $0.1 \%$.

Thus, information asymmetry does not result in a debt overhang, so that the company loses growth opportunities. The agency problem explains the conflict between managers and shareholders with debtholders. The presence of debt can stimulate opportunistic managerial behavior to reject growth opportunities with positive NPV because it only benefits debtholders. The use of growth opportunities is not determined by debt and size, but rather by firm age. Company size is a total asset that contains information asymmetry (Lang, et al., 1996), so that it has the potential to result in undervalued issued debt. Likewise, more debt issues result in control and monitoring of debtholders, so that companies do not issue debt to finance growth opportunities.

On the other hand, when firms are older and have a lower level of information asymmetry (Month and Yan, 2012; La Rocca, et al., 2011), they prefer equity over debt. Because it stimulates capital market evaluation due to equity issuance, managers who act to serve shareholders will prevent the decline stage by exploiting growth opportunities. 


\section{Conclusion}

With the characteristics of being dominated by a concentrated ownership structure and family, companies in Indonesia provide evidence that there is no excessive debt, let alone a debt overhang. Shareholders maintain a relatively smaller debt ratio than the assets in place used to take advantage of growth opportunities. This situation prevents conflicts between shareholders and debtholders due to underinvestment and risk shifting. Interestingly, when there is no agency conflict (cheap cost of debt) and older companies have low assimilation problems (access to equity issuance is better), the company should increase debt or issue equity. Shareholders still maintain low debt and do not increase equity because of low information asymmetry to avoid dilution. Overall, companies in Indonesia with a unique structure are the same as companies worldwide (La Porta, et al., 1999); they do not have a debt overhang problem. Older companies with low information asymmetry keep their debt relatively stable and use them in a limited way to take advantage of growth opportunities.

Companies with good quality will prefer debt to equity because shareholders prevent power dilution due to share issued (Leland and Pyle, 1977). Low-quality companies, in our study, have potential agency problems, not only avoiding losing power discretion through share issues, but also avoiding increasing debt to take advantage of growth opportunities. The research is conducted to prevent monitoring from larger external shareholders, namely debtholders and capital market evaluations.

The limitation of this research is that the study could not explore the variable of family ownership structure due to Indonesia's pyramid ownership structure. Future studies are suggested to use monthly pyramid ownership structure data to show the consistency of leverage, firm age, and firm size as a future research agenda. More factors should also be included in the regression model to capture more determinants of growth opportunities in the perspective of agency theory and asymmetric information, thereby reducing the gap between expected and realized results. Finally, the study performed several statistical tests to test the relevance of regression and found it consistent, showing that research data is reliable.

\section{$6 \quad$ References}

[1] Akerlof, G., 1970. The Market for "Lemons": Quality Uncertainty and the Market Mechanism. Quarterly Journal of FinanceJournal of Economics, 84 .

[2] Aminadav, G., Papaioannou, E., 2016. Corporate Control Around the World (Working Paper 23010; National Bureau of Economic Research).

[3] Bulan, L.T., Yan, Z., 2012. Firm Maturity and the Pecking Order Theory. SSRN Electronic Journal. https://dx.doi.org/10.2139/ssrn.1760505.

[4] Das, S., Roy, M. 2007. Inter-Industry Differences in Capital Structure: The Evidence from India. Finance India, 21(2), 517.

[5] La Porta, R., Lopez-de-Silanes, F., Shleifer, A. (1999). Corporate Ownership Around the world. Journal of Finance, 54(2), pp.471-517. https://doi.org/10.1111/0022-1082.00115.

[6] La Rocca, M., La Rocca, T., Cariola, A., 2011. Capital Structure Decisions During a Firm's Life cycle. Small Business Economics. https://link.springer.com/content/pdf/10.1007/s1 1187-009-9229-z.pdf.

[7] Lang, L., Ofek, E., Stulz, R.M., 1996. Leverage, Investment, and Firm Growth. Journal of Financial Economics, 40.

[8] Leland, H., Pyle, D., 1977. Information Asymmetries, Financial Structure, and Financial Intermediation. The Journal of Finance, 32. https://doi.org/10.1111/jofi.12742.

[9] Maria, M., Martina, L., Connor, O., 2019. The Determinants of SME Capital Structure Across the Lifecycle. ESRI Working Paper, No. 614; The Economic and Social Research Institute (ESRI), Dublin).

[10] Martinez, C., Lawless, M., O'Toole, C., 2019. The Determinants of SME Capital Structure Across the Lifecycle. The Economic and Social Research Institute (ESRI), Dublin.

[11] Qu, W., Wongchoti, U., Wu, F., Chen, Y., 2018. Does Information Asymmetry Lead to Higher Debt Financing? Evidence from China During the NTS Reform Period. Journal of Asian Business and Economic Studies, 25(1), pp.109-121. https://doi.org/10.1108/jabes-04-2018-0006. 